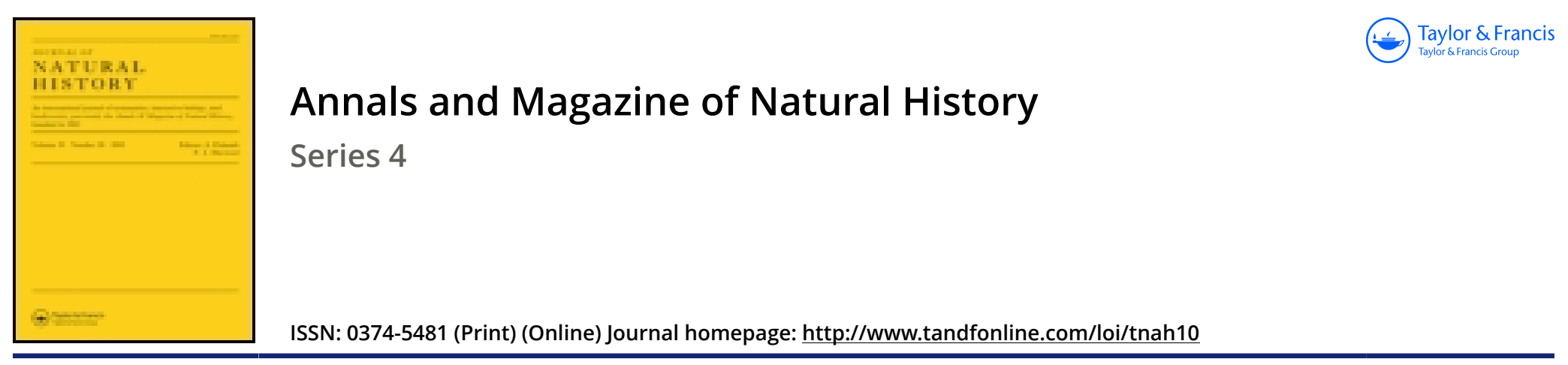

\title{
LIII._-On two Isopods, belonging to the genera Cirolana and Anilocra, new to the British Islands
}

\section{Rev. A.M. Norman M.A.}

To cite this article: Rev. A.M. Norman M.A. (1868) LIII.-On two Isopods, belonging to the genera Cirolana and Anilocra, new to the British Islands, Annals and Magazine of Natural History, 2:12, 421-422, DOI: 10.1080/00222936808695844

To link to this article: http://dx.doi.org/10.1080/00222936808695844

\section{Published online: 16 Oct 2009.}

\section{Submit your article to this journal $\square$}

Џ Article views: 5

Q View related articles ¿

Citing articles: 1 View citing articles $\square$ 


\section{EXPLANATION OF THE PLATES.}

\section{Prate XXI.}

Fig. 1. Haploops tubicola, Lilljeborg. Last pereiopod, $\times 40$.

Fig. 2. The same. Last uropod, $\times 40$.

Fig. 3. The same. Telson, $\times 40$.

Fig. 4. Nicippe tumida, Bruzelius. Gnathopod, $\times 40$.

Fig. 5. The same. Last pereiopod, $\times 40$.

Fig. 6. The same. Telson, $\times 40$.

Fig. 7. Eriopis elongata, Bruzelius. Second gnathopod, $\times 40$.

Fig. 8. The same. Last pereiopod, $\times 40$.

Fig. 9. The same. Last uropod (after Bruzelius).

Fig. 10. The same. Telson (after Bruzelius).

Fig. 11. Mara Lovéni, Bruzelius. First gnathopod, $\times 16$.

Fiy. 12. The same. Second gnathopod, $\times 16$.

\section{Plate XXII.}

Fig. 1. Mara Batei, Norman. First gnathopod, ơ , $\times 40$.

Fig. 2. The same. Second gnathopod, on, $\times 40$.

Fig. 3. The same. End of pleon.

Fig. 4. Tessarops hastata, Norman, $\times 16$.

Fig. 5. The same. Superior antenna, $\times 40$.

Fig. 6. The same. First gnathopod, $\times 40$.

Fig. 7. The same. Second gnathopod, $\times 40$.

Fig. 8. Helleria coalita, Norman. Fore part of body, $\times 40$.

\section{Plate XXIII.}

Fig. 1. Helleria coalita, Norman. Second gnathopod, $\times 40$.

Fig. 2. The same. Extremity of same, $\times 85$.

Fig. 3. The same. Last pereiopod, $\times 60$.

Fig. 4. The same. Last segment of pleon, $\times 40$.

Fig. 5. The same. Last uropod, $\times 60$.

Fig. 6. The same. Telson, $\times 63$.

Fig. 7. Microprotopus maculatus, Norman. First gnathopod, ð, $\times 85$.

Fig. 8. The same. Second gnathopod, $\delta, \times 85$.

Fig. 9. The same. First gnathopod, $8, \times 85$.

Fig. 10. The same. Second gnathopod, $q, \times 85$.

Fig. 11. The same. Telson and uropods, $\times 85$.

LIII.-On two Isopods, belonging to the Genera Cirolana and Anilocra, new to the British Islands. By the Rev. A. M. Norman, M.A.

[Plate XXIII. figs. 12-15.]

Crustacea Isopoda.

Fam. Fgidæ.

Cirolana truncata, n. sp. Pl. XXIII. figs. 12-15.

Head much wider than long; greatest width in the centre, at the projection of the eyes, narrower behind and in front, which is slightly tridentate. Superior antenno suddenly bent in a remarkable way at a right angle at the junction of the first and second joints of the peduncle, the first being projected directly forwards, the second directly transversely; third joint 
of peduncle much narrower and shorter than the second; flagellum consisting of only about four joints, the first of which is twice as long as the last of the peduncle, and longer than the rest of the flagellum. Inferior antennee very long and slender. Telson as broad as long; margins crenulated, distally truncate and denticulate; the two external teeth on each side larger than the row of intermediate ones. Last uropods having both branches truncate at the extremity.

Dredged in 40-60 fathoms on a muddy bottom, in St. Magnus Bay, Shetland, in the summer of 1867.

\section{Anilocra mediterranea, Leach.}

Anilocra mediterranea, Leach, Dict. des Sc. Nat. vol. xii. p. 350; Desmarest, Consid. sur les Crust. p. 306; M.-Edw. Atlas du Règne Animal de Cuvier, Crust. pl. 66. fig. 1; Hist. Nat. des Crust. vol. iii. p. 257 ; Savigny, Hist. de I'Egypte, Crustacés, pl. 11. fig. 10; Heller, Carcin. Beiträge zur Fauna des adriatis. Meeres (Verh. d. k.-k. zool.-botan. Gesellsch. in Wien, 1866), p. 19.

Body tumid, boldly arched, surface smooth, polished; colour black, mottled with yellow. Head narrower than pereion (which gradually increases in width to the hinder extremity of the fifth segment, whence it narrows posteally), projecting beyond the eyes into a process, which is as long as the rest of the head, nearly square, and bent downwards at the extremity. Eyes confined to the sides, their combined breadth not more than equalling half that of the head. Superior antenno not as long as the head, flagellum of four joints. Inferior antennoe short, reaching the middle of first segment of the pereion. Gnathopods and pereiopods glabrous, wholly devoid of spines or hairs; nails strong, hamate, and very sharply pointed. Last uropods with the inner branch only slightly exceeding half the length of the outer, subequal in length to telson; outer branch longer than peduncle, and much longer than telson, narrow, subfalciform, glabrous. Telson with a slight central keel, depressed near the base, rounded at the extremity, with smooth margins and polished surface. Length slightly exceeding one inch.

Found on small fish in rock-pools at Herm in $\mathbf{1 8 6 5 .}$

I sent a specimen to Mr. Spence Bate, for use in his work; and I conclude that it must have been by some oversight omitted, though the specimen is still in his hands.

EXPLANATION OF PLATE XXIII. figs. 12-15.

Fig. 12. Cirolana truncata, Norman. Head and antennæ, $\times 25$.

Fig. 13. The same. Mandible, $\times 40$.

Fig. 14. The same. One of the anterior pairs of feet, $\times 40$.

Fig. 15. The same. Telson, $\times 16$. 